\title{
Species Abundance, Occurrence and Diversity of Cricket Fauna (Orthoptera: Ensifera) in Rajshahi City, Bangladesh
}

Shah HA Mahdi*, Meherun Nesa, Manzur-E-Mubashsira Ferdous, Mursalin Ahmed

Department of Zoology, University of Rajshahi, Rajshahi 6205, Bangladesh

DOI: $10.36347 /$ sajb.2020.v08i09.003

| Received: 06.09.2020 | Accepted: 14.09.2020 | Published: 25.09.2020

*Corresponding author: Shah H. A. Mahdi

Abstract

Original Research Article

The present study was done to assess the species abundance, monthly occurrence and diversity of cricket fauna (Orthoptera: Ensifera) in Rajshahi City, Bangladesh. A total number of 283 individuals of cricket fauna were collected and they were identified into three families, six genera and seven species. The collected specimens belonged to three families such as Gryllidae (166), Tettigoniidae (59) and Gryllotalpidae (58). The seven species and their relative abundance were viz. Gryllus texensis (36.40\%), Gryllus campestris (18.37\%), Lepidogryllus comparatus (3.89\%), Neoconocephalus palustris (9.89\%), Scudderia furcata (4.95\%), Montezumina modesta (6.01\%) and Gryllotalpa gryllotalpa (20.49\%). Among them, highest population with dominance was Gryllus texensis (103) and lowest population was Lepidogryllus comparatus (11). Among the collected species, the status of Gryllus texensis, Gryllus campestris and Gryllotalpa gryllotalpa were very common (VC); Neoconocephalus palustris and Montezumina modesta were fairly common (FC) and Lepidogryllus comparatus and Scudderia furcata were considered as rare (R). Base on monthly occurrence 2 species of cricket were found throughout 12 months, 2 were 9-11 months, 2 were 6-8 months and 1 was 3-5 months. The highest species occurrence of cricket fauna was recorded in the month of August and lowest in January. Diversity indices of Shannon (H'), Simpson (1-D) and Margalef $\left(\mathrm{D}_{\mathrm{Mg}}\right)$ were 1.68, 0.77 and 1.06 respectively. Menhinick richness $\left(\mathrm{D}_{\mathrm{Mn}}\right)$, Berger-Parker dominance $(\mathrm{d})$ and Pielou's evenness index $\left(\mathrm{J}^{\prime}\right)$ were $0.42,0.36$ and 0.94 respectively. This works may help to find information regarding the abundance, occurrence and diversity of cricket fauna and may assist to understand the ecological aspect in this area. Perhaps this constitutes the first report on cricket fauna in the greater Rajshahi Division.

Keywords: Species abundance, monthly occurrence, species diversity, diversity index, Orthoptera, Ensifera, cricket fauna.

Copyright @ 2020: This is an open-access article distributed under the terms of the Creative Commons Attribution license which permits unrestricted use, distribution, and reproduction in any medium for non-commercial use (NonCommercial, or CC-BY-NC) provided the original author and source are credited

\section{INTRODUCTION}

Crickets (Orthoptera: Ensifera) are the important group of insect related to grasshoppers and its order Ensifera is believed to be an ancient group of organism which originated in the Carboniferous period [1]. This group of insect used as a key bioindicator to estimate the species diversity, abundance and bionomics in an area [2-4]. The crickets can be serious pests of vegetable crops due to their herbivorous feeding behavior and significant damage to crop associated with horticultural crops [5]. It has been reported that some of the species belonging to Ensifera (Orthoptera) are important pests of agricultural crops, orchard and forest [6]. Crop damage increases the probability of introducing plant pathogens onto the seedlings [7]. Finley [8] reported that use of insect protein, such as cricket flour, could be critical in feeding the growing population of the world while being less damaging to the environment.

Crickets are worldwide in distribution and approximately 2,400 species of leaping insects were reported [9]. Crickets vary in length from 3 to $50 \mathrm{~mm}$ (0.12 to 2 inches) and the largest members of the family are the bull crickets, Brachytrupes, which are up to $5 \mathrm{~cm}$ (2 in) long. As some of the species belonging to Ensifera (Orthoptera) are important pests of agricultural crops, orchard and forest and considerable taxonomic work have been done on Ensifera (Tettigonioidea) by various authors [10, 11]. Zoological Survey of India has mentioned about the suborder Ensifera includes 515 species, 184 genera and 10 families, namely Gryllidae (231 species and 72 genera), Trigonidiidae (22 species and 08 genera), Gryllotalpidae (08 species and 02 genera), Mogoplistidae (14 species and 07 genera), Myrmecophilidae (04 species and 01 genera), Prophalangopsidae (01 species and 01 genus), 
Rhaphidophoridae (14 species and 04 genera), Schizodactylidae (03 species and 01 genus), Anostostomatidae (06 species 05 genera), Gryllacrididae (49 species and 14 genera), Stenopelmatidae (03 species and 01 genus) and Tettigoniidae (160 species and 68 genera) [12].

Species diversity, seasonal abundance and morphometric analysis of grasshopper (Orthoptera: Caelifera) in Rajshahi City, Bangladesh were completed and a total number of 286 individuals of grasshopper under 2 families, 7 genera and 8 species were reported previously [13]. However, no mentionable work on the species abundance, monthly occurrence and diversity of cricket fauna in Bangladesh has been done. Therefore, the main goal of this study was to investigate the species abundance, occurrence and diversity of cricket fauna (Orthoptera: Ensifera) in Rajshahi City of Rajshahi District. Hopefully, this work will be first of its kind and will be a great help to understand the ecological aspect in this area.

\section{MATERIALS AND METHODS}

Study area: Cricket fauna were collected from Rajshahi City of Rajshahi District, Bangladesh. Rajshahi City area is $96.68 \mathrm{sq} \mathrm{km}$ and the geographical distribution of Rajshahi is between $24^{\circ} 20^{\prime}$ North and $88^{\circ} 36^{\prime}$ East.

Sampling Method: Cricket fauna collections were done from July 2017 to June 2018. Samples were collected randomly in every month for four times between $8 \mathrm{am}$ to $3 \mathrm{pm}$ in twelve different sites of the study area. Sweep net and hand picking method were used for collection the samples [14]. Then, collected specimens were narcotized with menthol (naphthalene) crystals and brought into the Crop Protection and Toxicology Laboratory, Department of Zoology, University of Rajshahi and air dried for $24 \mathrm{~h}$.

Identification: All cricket fauna were identified to the lowest taxonomic level using standard a identification key or manual $[15,16]$. The external features and the color of specimens were used for identification. Pictures of species were taken using a DSLR camera (Canon 750D). Then, identified specimens were labeled and preserved in insect boxes according to species and tagged with certain number.

Status of cricket fauna: According to number of sightings, categorized cricket fauna status into VC, Very Common (> 50 sightings); C, Common (31-50 sightings); FC, Fairly Common (16-30 sightings); R, Rare (6-15 sightings) and VR, Very Rare (1-5 sightings) [17].

Data Analysis: All data were subjected to analysis with the help of Microsoft Excel office 2007. Relative abundance was determined using the formula [18]:

$$
\text { Relative Abundance }(R A)=\frac{\text { Number of individuals }}{\text { Total number of species }} \times 100
$$

Following diversity indices were used to estimate the biodiversity of cricket fauna in the study area.

1. Shannon Diversity Index: This index is commonly used to characterize species diversity in a community based on mathematical theory of communication proposed by Shannon [19].

$$
H^{\prime}=-\sum_{i=1}^{S} p_{i} \ln p_{i}
$$

H': Shannon diversity index

$\mathrm{p}_{\mathrm{i}}$ : The proportion $(\mathrm{n} / \mathrm{N})$ of individuals of one particular species

Ln: The natural logarithm

$\mathrm{S}$ : Total number of species
2. Simpson Diversity Index: It is a diversity index given by Simpson [20]. Simpson index (D) values are between 0 and 1 .

$$
1-D=\sum_{i=1}^{S} p_{i}^{2}
$$

D: Simpson diversity index

$\mathrm{p}_{\mathrm{i}}$ : Number of individuals belonging to i species

$\mathrm{S}$ : Total number of species

3. Margalef Diversity Index: Margalef's index was used as a simple measure of species richness [21].

$$
D_{M g}=\frac{(S-1)}{\ln N}
$$

$\mathrm{D}_{\mathrm{Mn}}$ : Margalef diversity index

S: Total number of species

$\mathrm{N}$ : Total number of individuals

Ln: The natural logarithm 


\section{Menhinick Richness Index: Menhinick index,} like Margalef index, attempts to estimate species richness but at the same time it is independent of the sample size [22].

$$
D_{M n}=\frac{S}{\sqrt{N}}
$$

$\mathrm{D}_{\mathrm{Mn}}$ : Menhinick richness index

S: Total number of species

$\mathrm{N}$ : Total number of individuals

5. Berger-Parker Dominance Index: This index is an intuitively simple dominance measure, and expresses the proportional abundance of the most abundant species [23].

$$
d=\frac{N_{\max }}{N}
$$

d: Berger-Parker dominance index

$\mathrm{N}_{\max }$ : The number of individuals of the most abundant species

$\mathrm{N}$ : Total number of individuals
6. Pielou's Evenness Index: It was derived from the Shannon index by Pielou [24]. The ratio of the observed value of the Shannon index to the maximum value gives the Pielou Evenness Index result. The values are between 0 and 1 .

$$
J^{\prime}=\frac{H^{\prime}}{H_{\max }}
$$

$\mathrm{J}^{\prime}$ : Pielou evenness index

$H^{\prime}$ : The observed value of Shannon-Wiener index $\mathrm{H}_{\max }: \ln \mathrm{S}$

S: Total number of species Ln: The natural logarithm

\section{RESULTS AND DISSCUSSION}

Cricket Fauna (Orthoptera: Ensifera) were collected from July 2017 to June 2018 from different sites in Rajshahi City. A total of 283 individuals was collected during the study period. The collected cricket fauna belong to 3 families, 6 genera and 7 species (Table 1). The highest number of species was recorded in family Gryllidae $(\mathrm{n}=166)$ and lowest in Gryllotalpidae $(\mathrm{n}=58)$ (Table 1, Figure 1).

Table-1: Species abundance and monthly occurrence of collected individuals of different species of cricket fauna in Rajshahi City. 1, January; 2, February; 3, March; 4, April; 5, May; 6, June; 7, July; 8, August; 9, September; 10, October; 11, November

\begin{tabular}{|c|c|c|c|c|c|c|c|c|c|c|c|c|c|c|c|}
\hline \multirow{2}{*}{ Family } & \multirow{2}{*}{ Species name } & \multicolumn{12}{|c|}{ Species abundance and monthly occurrence of individuals } & \multirow{2}{*}{ Total } & \multirow{2}{*}{ Status } \\
\hline & & 1 & 2 & 3 & 4 & 5 & 6 & 7 & 8 & 9 & 10 & 11 & 12 & & \\
\hline \multirow{3}{*}{ Gryllidae } & Gryllus texensis & 2 & 2 & 8 & 9 & 10 & 12 & 17 & 20 & 12 & 5 & 3 & 3 & 103 & $\mathrm{VC}$ \\
\hline & Gryllus campestris & 0 & 4 & 4 & 5 & 5 & 8 & 8 & 10 & 5 & 2 & 1 & 0 & 52 & VC \\
\hline & $\begin{array}{l}\text { Lepidogryllus } \\
\text { comparatus }\end{array}$ & 0 & 0 & 0 & 0 & 0 & 2 & 2 & 3 & 2 & 2 & 0 & 0 & 11 & $\mathbf{R}$ \\
\hline \multirow{3}{*}{ Tettigoniidae } & $\begin{array}{l}\text { Neoconocephalus } \\
\text { palustris }\end{array}$ & 1 & 2 & 2 & 2 & 2 & 2 & 4 & 5 & 3 & 3 & 2 & 0 & 28 & FC \\
\hline & Scudderia furcata & 0 & 0 & 0 & 1 & 1 & 2 & 3 & 4 & 1 & 1 & 1 & 0 & 14 & $\mathbf{R}$ \\
\hline & Montezumina modesta & 0 & 1 & 2 & 2 & 2 & 2 & 3 & 4 & 1 & 0 & 0 & 0 & 17 & FC \\
\hline Gryllotalpidae & $\begin{array}{l}\text { Gryllotalpa } \\
\text { gryllotalpa }\end{array}$ & 2 & 3 & 4 & 4 & 3 & 9 & 5 & 12 & 4 & 6 & 3 & 3 & 58 & VC \\
\hline \multicolumn{2}{|c|}{ Total (Monthly) } & 5 & 12 & 20 & 23 & 23 & 37 & 42 & 58 & 28 & 19 & 10 & 6 & 283 & \\
\hline
\end{tabular}
and 12, December. Based on number of sightings, categorized cricket fauna status into VC, Very Common (> 50 sightings); $C$, Common (31-50 sightings); FC, Fairly Common (16-30 sightings); R, Rare (6-15 sightings) and VR, Very Rare (1-5 sightings)

Among them, Gryllus texensis was maximum in number (103) followed by Gryllotalpa gryllotalpa (58), Gryllus campestris (52), Neoconocephalus palustris (28), Montezumina modesta (17), Scudderia furcata (14) and Lepidogryllus comparatus (11) (Table 1). 


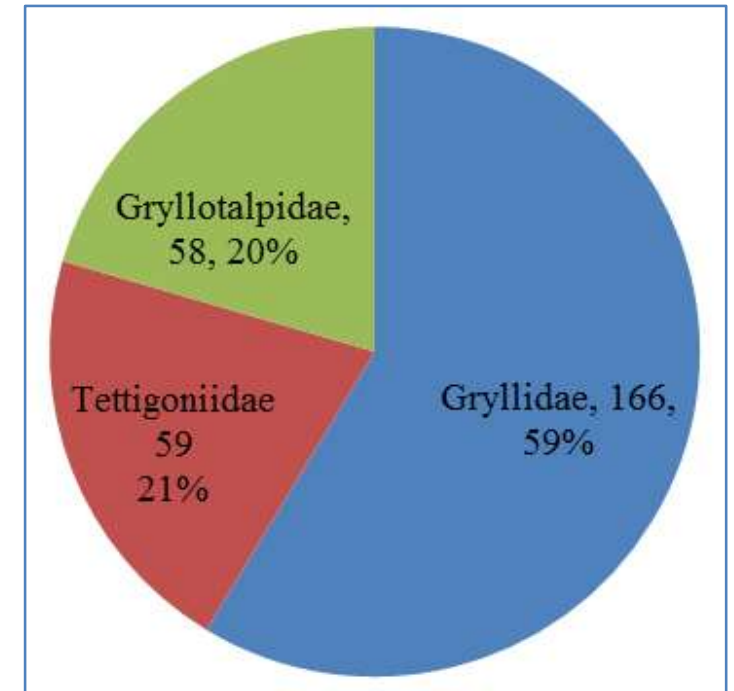

Fig-1: Family wise diversity (number and percentage) of cricket fauna $(n=283)$

The relative abundances (RA) of seven species were viz. Gryllus texensis (36.40\%), Gryllus campestris (18.37\%), Lepidogryllus comparatus (3.89\%), Neoconocephalus palustris $(9.89 \%)$, Scudderia furcata (4.95\%), Montezumina modesta (6.01\%) and Gryllotalpa gryllotalpa $(20.49 \%)$ (Figure 2). As I mentioned in materials and methods chapter, categorized cricket fauna status into VC, Very Common (> 50 sightings); C, Common (31-50 sightings); FC, Fairly Common (16-30 sightings); R, Rare (6-15 sightings) and VR, Very Rare (1-5 sightings) according to number of sightings [17]. In this study, the status of Gryllus texensis, Gryllus campestris and Gryllotalpa gryllotalpa were very common (VC); Neoconocephalus palustris and Montezumina modesta were fairly common (FC) and Lepidogryllus comparatus and Scudderia furcata were considered as rare (R) (Table 1). Only three categories of individuals were found in the study.

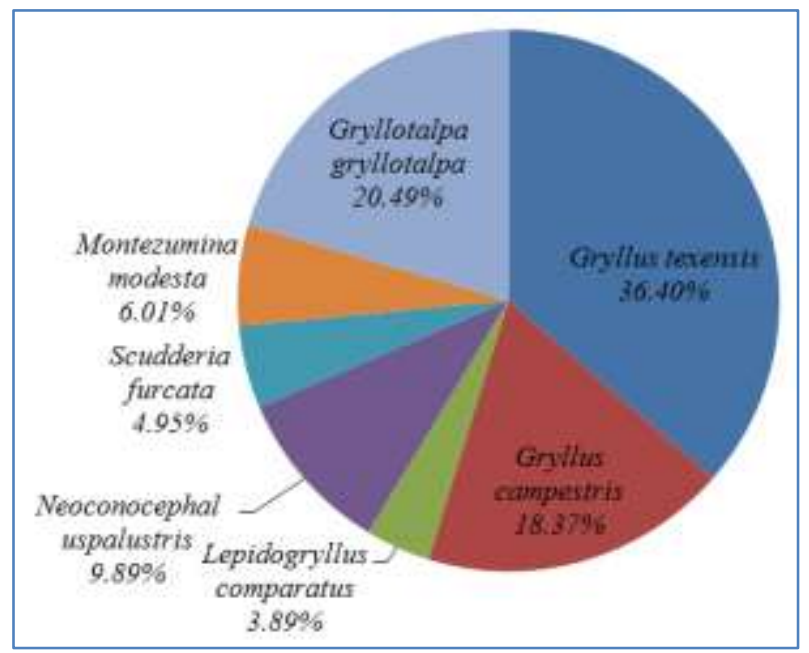

Fig-2: Relative abundances (RA) of cricket fauna $(n=283)$

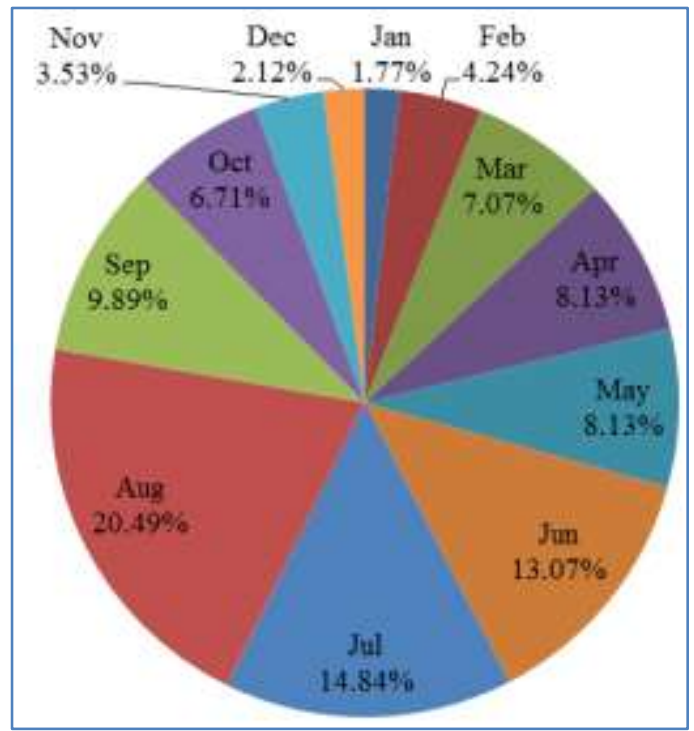

Fig-3: Monthly diversity (percentage) of cricket fauna $(n=283)$

Base on monthly occurrence 2 species of cricket were found throughout 12 months, 2 were 9-11 months, 2 were $6-8$ months and 1 was $3-5$ months (Table 1 ). The highest species occurrence of cricket fauna was recorded in the month of August (20.49\%) and lowest in January (1.77\%) (Figure3). The value of Shannon-Wiener diversity index 1.68, the Value of the Simpson diversity index 0.77 , and the Margalef diversity index was 1.09. Menhinick richness and Berger-Parker dominance were 0.42 and 0.36 respectively. Cricket fauna evenness estimated by Pielou's evenness index which was 0.89 (Table 2).

Table-2: Values of different diversity indices of cricket fauna in Rajshahi City

\begin{tabular}{|l|c|}
\hline Name of indices & Values \\
\hline Shannon diversity index $\left(\mathrm{H}^{\prime}\right)$ & 1.68 \\
\hline Simpson diversity index $(1-\mathrm{D})$ & 0.77 \\
\hline Margalef diversity index $\left(\mathrm{D}_{\mathrm{Mg}}\right)$ & 1.06 \\
\hline Menhinick richness index $\left(\mathrm{D}_{\mathrm{Mn}}\right)$ & 0.42 \\
\hline Berger-Parker dominance index $(\mathrm{d})$ & 0.36 \\
\hline Pielou's evenness index $\left(\mathrm{J}^{\prime}\right)$ & 0.94 \\
\hline
\end{tabular}

This is the first report of cricket (Orthoptera: Ensifera) in Rajshahi City. In result of this study, a total of 283 individuals were identified under 03 families i.e. Gryllidae (3 species and 2 genera), Tettigoniidae (3 species and 3 genera) and Gryllotalpidae (1 species and 1 genus). A similar result has been reported in Pakistan that a total of 242 specimens were sorted out into 03 families such as Phaneropterinae, Conocephalinae and Gryllinae [6]. Checklist of suborder Ensifera of India included the families such as Gryllidae (231 species and 72 genera), Tettigoniidae (160 species and 68 genera) and Gryllotalpidae (08 species and 02 genera) [12]. A total of 13 species of Tettigonioidea were reported in whole Pakistan and 8 species from Sindh [10, 11]. 
In this study, three categories of cricket species were found viz. Gryllus texensis, Gryllus campestris and Gryllotalpa gryllotalpa were very common (VC); Neoconocephalus palustris and Montezumina modesta were fairly common (FC) and Lepidogryllus comparatus and Scudderia furcata were considered as rare (R). Another study on butterflies, Tiple et al. [25, 26] categorized butterfly status into VC, very common (> 100 sightings); C, common (50-100 sightings); NR, not rare (15-50 sightings); $\mathrm{R}$, rare (2-15 sightings); VR, very rare $(<2$ sightings). The present study reviled the study area as a general habitat by Shannon-Wiener diversity index (value 1.68). For this index, values are between 0.0 and 5.0, and results are generally between 1.5 and 3.5 [19]. The value of Simpson diversity index ranges between 0 and 1 [20]. In this study, the value of Simpson index is 0.77 , indicating the fairly rich habitat. Margalef diversity index is 1.06 , and it has no limit value (extend beyond 1) [21]. The values Pielou's evenness index are between 0 and 1 . In our study, the value Pielou's evenness index is 0.94 which closer to 1 , it means that the individuals are distributed equally [24]. Rain et al. [27] recorded all the diversity indices and evenness indices of the spider fauna in Jahangirnagar University in Bangladesh, and their results were generally close and resemble to our study on cricket fauna.

\section{CONCLUSION}

Measuring species abundance, monthly occurrence and diversity are important components of many ecosystems for conservation biology. In this study, a checklist of seven species of cricket fauna out of 283 individuals was made from different sites in Rajshahi City, Bangladesh. Gryllidae is the largest contributor, and the population of Gryllus texensis is the highest among cricket species. The highest occurrence had been observed in August. Based on sightings Gryllus texensis, Gryllus campestris and Gryllotalpa gryllotalpa were very common, and two species were found throughout the year. To our knowledge, this is the first report on abundance, occurrence and diversity of cricket fauna not only Rajshahi City, but also greater Rajshahi Division. Therefore, this works may provide the latest status about biodiversity and taxonomy of crickets in all over Bangladesh.

\section{ACKNOWLEDGEMENT}

The authors expressing sincere thanks to the Chairman, Department of Zoology, University of Rajshahi, Bangladesh for providing laboratory facilities. The authors are also thankful to the laboratory members of Crop Protection \& Toxicology of same department and university for species collection.

\section{REFERENCES}

1. Resh VH, Cardé RT. Encyclopedia of Insects. Academic Press; 2009.
2. Pfadt RE. Species richness, density, and diversity of grasshoppers (Orthoptera: Acrididae) in a habitat of the mixed grass prairie. The Canadian Entomologist. 1984, 116: 703-09.

3. Joern A, Gaines SB. Population dynamics and regulation in grasshoppers. In: Biology of grasshoppers. Chapman RF, Joern A editors, Wiley, New York. 1990; 415- 482.

4. Lockwood JA. Rangeland Grasshopper Ecology. In: Bionomics of grasshoppers. (Eds. Gangewere SK, Muralirangan MC, Muralinrangan M editors, Katydids and their Kins, CABI, London. 1997; 83-102.

5. Schuster DJ, Price JF. Seedling feeding damage and preference of Scapteriscus spp. Mole crickets (Orthoptera: Gryllotalpidae) associated with horticultural crops in West-Central Florida. Florida Entomologist. 1992; 75: 115-19.

6. Bozdar MI, Sultana R. Discovery of Ensifera (Orthoptera) from Khairpur Mir's. Journal of Entomology and Zoology Studies. 2018; 6(4): 913-915.

7. Hudson WG. Other behavior, damage, and sampling. In: Mole crickets in Florida. Walker TJ editor. Florida Agric. Exp. Bull. 1985; 846: 16-21.

8. Finley K. You'll eat bugs. These investors are betting millions on it". Wired Archived. 2019.

9. Cricket. Available from https://www.britannica.com/animal/cricket-insect

10. Sultana R, Wagan MS, Panhwar WA. Distribution and incidence of Tettigonioidea (Ensifera) Orthoptera from Sindh Pakistan. Pakistan Journal of Entomology. 2012; 27: 117-22.

11. Sultana R, Panhwar WA, Wagan MS. Keys for identification of long-horned grasshoppers Tettigonioidea (Ensifera) occurring in Pakistan. Pakistan Journal of Entomology. 2013; 28(2):113-6.

12. Chandra K, Gupta SK, Shoshodia MS. A checklist of Orthoptera (Insecta) of India. Zoological Survey of India (MP), India. 2010; 1-57.

13. Mahdi SHA, Ahmed M, Ahsan MK. Species diversity, seasonal abundance and morphometric analysis of grasshopper (Orthoptera: Caelifera) in Rajshahi city, Bangladesh. Serangga. 2018; 23(1): 24-34.

14. Sanjayan KP. Relationship between grasshopper and crops in an agroecosystem of Tamil Nadu, India. Beiträge zur Entomologie. 1994; 44(1): 232-241.

15. Kirby WF. The fauna of British India, including Ceylon and Burma. Orthoptera (Acrididae). London; 1914.

16. Bug guide. Suborder Caelifera - Grasshoppers. Available from https://bugguide.net/node/view/16133

17. Chowdhury S, Aich U, Dash MK. Checklist of butterfly fauna of Dinajpur, Bangladesh. Journal of Entomology and Zoology Studies. 2014; 2 (5): 156-159. 
18. Alias, Hadi UK, Retnani EB. Diversity and abundance of cockroaches (Insecta: Dictyoptera) in ships at Bau-Bau port. Journal of Entomology and Zoology Studies. 2018; 6(3): 29-34.

19. Shannon CE. The mathematical theory of communication. The Bell System Technical Journal. 1948; 27: 379-423 and 623-656.

20. Simpson EH. Measurement of diversity. Nature. 1949; 163: 688.

21. Margalef R. Information theory in Ecology. International Journal of General Systems. 1958; 3: 36-71.

22. Menhinick EF. A comparison of some species-individuals diversity indices applied to samples of field insects. Ecology. 1964; 45: 859-861.

23. Berger WH, Parker FL. Diversity of planktonic Foraminifera in deep sea sediments. Science. 1970; 168: $1345-1347$.
24. Pielou EC. The Measurement of Diversity in Different Types of Biological Collections. Journal of Theoretical Biology. 11966; 3: 131-144.

25. Tiple AD, Deshmukh VP, Dennis RLH. Factors influencing nectar plant resource visits by butterflies on a university campus: Implications for conservation. Nota Lepidopterologica. 2006; 28: 213-224.

26. Tiple AD, Khurad AM, Dennis RLH. Butterfly diversity in relation to a human-impact gradient on an Indian university campus. Nota Lepidopterologica. 2007; 30(1): 179-188.

27. Rain FF, Howlader AJ, Bashar K. Diversity and abundance of spider fauna at different habitats of Jahangirnagar University Campus, Bangladesh. Journal of Entomology and Zoology Studies. 2016; 4(5): 87-93. 